\title{
UKRANIAN LANGUAGE AND SONGS PLAYED ON THE RADIO IN ORDER TO GUARD AND PRESERVE ONE'S OWN CODE IN EMIGRATION
}

\section{HIRINA Tetyana,}

PhD (Social Communications), Associate Professor, Doctoral student,

Taras Shevchenko National University of Kyiv, The Institute of Journalism, 36/1, Melnykova St., Kyiv, 04119, Ukraine, e-mail: hirinatetyana@gmail.com

Analyzed the role of and describes the value of the native language in the radio programs produced by Ukrainians in different countries as a powerful integration factor in the global Ukrainian community. 141 cities have been identified in 32 countries of the world in radio broadcast of which between the years 1922-2017 the Ukrainian language and songs were played.

According to the study of Ukrainian periodicals in Canada, USA and Germany, the author interprets the musical component of the radio programs of the Ukrainian emigration. It is established that through song, talented singers and collectives on all continents acquainted listeners of various ethno-national groups with original Ukrainian culture.

Key words: world media environment, the world community of Ukrainians, Ukrainian song, Ukrainian radio.

\section{ПРОМОВЛЕНЕ ТА ПРОСПІВАНЕ НА РАДІО УКРАЇНСЬКЕ СЛОВО НА ВАРТІ ЗБЕРЕЖЕННЯ НАЦІОНАЛЬНОГО КУЛЬТУРНОГО КОДУ В ЕМІГРАЦІЇ}

Проаналізовано роль та описано иінність рідної мови у радіопрогралах продукованих українияли в різних країнах як потужного інтеграційного чинника глобальної украӥнської гролади. Визначено 141 місто у 32 країнах світу в радіопросторі яких у 1922-2017 рр. звучала українська мова та пісня. За результатали вивчення української періодики Канади, США та Нілеччини автор ослислює музичну складову радіопрограм української еліграції. Встановлено, що через пісню талановиті співаки та колективи на всіх континентах знайолили слухачів різних етнонаціональних груп з салобутньою українською культурою.

Ключові слова: світове медіасередовище, світове співтовариство украӥнців, українська пісня, украӥнськоловне радіо.

tatement of the problem. The Ukrainian language, the use of which was earlier and $\bigcirc$ still artificially remains the subject of manipulation, was an indicator of the national maturity of society. No wonder Ukrainians were so happy with the world premiere of radio when the Ukrainian speech and song could be heard from the receivers. In Ukraine, scientific literature has not yet systematically outlined the achievements and experience of foreign Ukrainians in creating a national patriotic radio product in conditions of external challenges and objective internal problems that faced the society. The historical context of this issue in terms of the use of the Ukrainian language as a marker of national identity and patriotism will be considered in this article.

Analysis of recent researches and publications. The stages of formation and directions of development of radio broadcasting in Ukraine have been described in various aspects in the works of V. Lyzanchuk, A. Goian, V. Goian, I. Khomenko, I. Mashchenko, archival materials (1942-1969.) on the history of the national radio broadcast studied N. Sidorenko. Valuable to us are the results of the scientific colloquium on «the history

(C) Hirina T., 2018 
of Ukrainian television», by V. Rizun, O. Goian. The participants focused on the origin of radio broadcasting in the world, the peculiarities of Ukrainian radio of the period, analyzed his musical nature [5]. The works of M. Kabanov and I. Penchuk are important for us from the point of view of a systematic view of the development of television and radio broadcasting in Ukraine.

The purpose of the article - to investigate the role and describe the value of the native language in radio programs produced by Ukrainians in different countries as a powerful integration factor of the global Ukrainian community in the 20th century.

Materials and methods. The monitoring of the press organs of the Ukrainian diaspora in the United States, Canada and Germany covered more than 14,500 issues of publications in 1922-2017. This made it possible to document the presence of Ukrainian-language radio initiatives on radio airwaves of 32 countries: Australia, Austria, Argentina, Belgium, Brazil, the Vatican, the United Kingdom, Venezuela, the Netherlands, Spain, Italy, Kazakhstan, Canada, China, Lithuania, Malta, New Zealand, Paraguay, Poland, Portugal, Romania, Serbia, Singapore, Slovakia, USA , Tunisia, Hungary, Uruguay, the Czech Republic, Chile and Sweden. In different years Ukrainian programs were broadcast in 141 cities on all continents. More broadly, the geography of programs was traced in places of registration of powerful public organizations of Ukrainians, however, even with minimal opportunities, they tried to initiate, if not a permanent, at least festive, non-periodic music program or the Liturgy.

The tasks set by the author became possible thanks to the use of a set of theoretical and theoretical-empirical research methods: analysis, induction, historiographical method, the method of monitoring periodicals, the synthesis and systematization of data.

Statement of the main material of the study. In 1929, inspired by one of the first issues of the "Ukrainian Hour», listeners were united by the purpose of its periodicity: «Everyone attends a constant Ukrainian hour on the radio to hear the native word in the house from the air». Almost everyone promises help and only asks how it can help» [15, p. 3]. The linguistic design of such programs has never been the subject of discussion.

In 1944, even the Bolsheviks, by organizing propaganda programs for Ukrainians in the US, used the Ukrainian and «Carpathian-Ukrainian» languages. "Let the Bolsheviks go even further in their dispersal. From the «Carpathian-Russian» radio program, they in a little on the Lemko and a little in the Katsap languages launch news about fantastic events in the «Subcarpathian Rus» [3, p. 4].

Ukrainians deviated from the rule of conducting their programs in their native language only in cases where knowledge of culture and the people as a whole was distributed in the languages of indigenous people.

Such programs consisted of a radio speech pronounced by an influential political or cultural figure of the Ukrainian community, after which, necessarily, a concert part, as the Ukrainian song did not leave any listener indifferent. At the same time, the conditions under which Ukrainians worked on popularizing their own culture in the world and even informing about its existence were far from ideal. Often the media complained that Ukrainians in radio programs of different countries were represented by Russians, and cultural and artistic achievements were attributed to the country's eastern neighbor. Such cases caused a storm of indignation in the society, which resulted in convergence in the opinion of the need to use any opportunities for acquainting the world with Ukraine. So in 1922, the American daily newspaper «The Detroit News» organized radio concerts of ethnic groups that were represented in the local community. The Ukrainian issue, widely advertised on the radio and on the pages of the publication, was presented to listeners as an evening of Russian music. In response, Ukrainians noted that «this is not unimportant and it is necessary to pay attention to such things. American journalists are little acquainted with our business and therefore such misunderstandings often come to the detriment of the Ukrainian cause» [21, p. 3]. Such cases have repeatedly 
happened on the air of the radio station «WEAF» (USA). For example, on July 13, 1928, the presenter of the program said that the Ukrainian hopak «resembles Russian folk art» $[8$, p. 3].

Herefore, to start working with local residents radio journalists had to get acquainted with Ukraine. Typical is the example of the Ukrainian program on «Rádio Guairacá» in Brazil. On May 16, 1951, the first release of the program began with the block «about Ukraine in the Brazilian language, and it is clearly emphasized that the Ukrainians are not Poles and not Russians, with whom Ukrainians are often confused in Brazil. After that, there were several Ukrainian songs» [20, p. 3]. And on the air of the Lithuanian radio station in Kovno (now Kaunas-Lithuania) on March 14, 1924, at 7.00 pm, four speeches were made in different languages about Eastern Galicia: "The first spoke in Lithuanian Dr. Puritskis; the second, in Ukrainian Mr. Bartowicz; the third, in Polish, Professor M. Birzhishka. The fourth speech was delivered in German" [2, p. 1]. In the future, similar projects in the country continued, but in the form of separate issues, rather than a periodic program.

Since those years to the present, multicultural platforms consisted of programs in both languages. However, in those cases when the culture of each country was perceived separately, there were no conflict situations. On January 22, 1984, the radio station «WDLC-Port Jervis» (NY, USA) broadcast a religious Ukrainian program «dedicated to the sixty-sixth anniversary of the proclamation of Ukraine's independence. A broad overview of this historic event was given in English, Russian and Ukrainian. The listeners were informed about the program of celebrations in Kerhonkson, Glen Spey and in Albany» [22, p. 4].

Now in the USA there functions «BFG Radio» - a 24-hour Internet radio station with the tagline «Ukrainian \& Russian speaking radio in USA». Conversational programs and music blocks here alternate organically forming a competitive media space for representatives of both nationalities in North America. The success of the project lies not in the denial of one culture and the superiority of one over the second, but in congruence with each other as good neighbors, including the etheric.

The struggle for their own national media space, which was poured on islands and peninsulas on all continents, according to the dissident and linguist S. Karavansky, has become a powerful test of strength for the Ukrainian language. In 2000, the researcher argued reasonably that «Over the past 65 years, a number of experiments have been carried out over the Ukrainian language, as a result of which her teaching became boring and uninteresting. The same thing happened with the language used in newspapers, textbooks, on radio and television» [6, p. 179].

In this context, the fertile soil for popularization at all times was music, the cultural heritage of one of the singers on the world's richest songs. "How nice it is to come on Sunday from church, have lunch, sit by the radio and listen to a Ukrainian song,» wrote the Ukrainians in the United States in 1935, "that for the satisfaction of coming home from work tired and after dinner listening to your song!» [4, p. 3].

Of course, the acquaintance of the world with Ukraine in the era of radio began with the song, and even more so, the first words in Ukrainian were heard all over the world during this time. That's why skilful performers of folk compositions were invited to make speeches and do interviews even on radio stations, on the air of which there were no separate programs in the Ukrainian language. For example, on September 9, 1924, on the air of a German radio station, "the Ukrainian tenor of the Königsberg opera, A. Ruskak, sang the Ukrainian folk songs between 8 and 9.30 in the evening» [18, p. 1]. On March 24, 1925 in Frankfurt (Germany) had a performance on the radio, another Ukrainian singer Y. Stetsyuk: «baritone singer, sang on that day with the accompaniment of the orchestra, several (11) Ukrainian songs from the collection of Sochinskiy-Ludkevich for the evening radio concert» $[11, \mathrm{p} .2]$. 
On March 15, 1926 on the radio «WBAX» (USA) V. Kraikovsky sang «two famous Lysenko's compositions» : «Getman» and «Oi, Dnipro» [12, p. 1]. The Ukrainian opera singer S. Korenets performed in March 1927 with a concert on the radio in Vienna (Austria), and the Ukrainian M. Menczinsky, who lived in Stockholm (Sweden) in 1928 on May 2 at the capital radio station performed "Ukrainian compositions, and namely the authorship of N. Lysenko to the words of T. Shevchenko: "The wind blows through the oak», "The lights are burning» ... «The snow has blazed.». In conclusion, Mencinsky sang «Ukraine has not died yet» (anthem of Ukraine) [7, p. 1]. The talent of the Ukrainians made such programs desirable for radio stations of different countries, and the number of positive responses in the form of letters received by the editors each time was startling.

The popularization of Ukrainian songs on the radio took place in conjunction with the development of radio technologies, actually developing in its mainstream. In 1929, in Ukrainian society, they stated: "People began to go to concerts less». The reason for the decrease in the interest of the Ukrainian public to attend concerts can be explained by the fact that now many of our Ukrainians have a radio in their home, including which they listen to different songs» [1, p. 3]. From year to year, Ukrainian songs became more and more widely available on the radio. Radio not only created conditions for mass acquaintance with Ukrainian culture for representatives of different nationalities, but also promoted the popularization of songs among Ukrainians, emphasizing the richness, originality and relevance of our culture.

Even more, in 1944, in his study of Ukrainian music S. Marusevich argued reasonably that Ukrainian culture, including radio, can open the world up to a lot of musical compositions. As an example, the author quoted the popular "Shchedrika" in the United States, which «is sung many times at concerts, schools, on the radio by outstanding choirs all over America with such names as "Ring out wild bells" or "Blue birds". Fortunately, everyone recognizes that this song is of Ukrainian origin" [10, p. 199]. To better understand what the Ukrainians are singing, some radio stations even translated texts, re-singing them for an authentic motif. Similar examples are recorded in the United Kingdom, the United States and other countries. But not only folk music is rich in Ukraine. Contemporary works picked up by radio stations and with the light hand of talented performers, also became popular in the world. The musicologist, the son of the world-famous composer and teacher R. Savitsky, R. Savitsky Jr., while exploring the Ukrainian composer's heritage in 2000, recalls L. Reutsky, the composer whose Symphony p. 2, as one of the best manifestations of Ukrainian neo-romanticism and impressionism "performed in 1953 the Detroit Orchestra (one of the best in North America), also sang the orchestra of Sacramento, the capital of California. Records of this symphony were heard on radio stations in New York, Philadelphia and other cities» [13, p. 127]. In different years the radio was popularized by means of radio written by contemporaries-composers L.Koloduba, (works were broadcast by radio stations in the USA), A. Gnatishin (in Austria), F. Yakimenko (in France), J. Fial (in Canada), etc. Radio listeners well knew the voices of Ukrainian singers L. Grabova, M. Staritsky, K. Tsisyk, etc. R. Savitsky states that in the second half of the 20 th century, "Proportional to its artistic value, Ukrainian music sounded in prestigious halls, in colleges, universities in radio and television programs in Americ» [14, p. 173].

Despite the fact that music has no nationality, Ukrainian motifs, and the skill of performers, were highly appreciated by critics. For example, after the concert on April 16, 1952 on the Spanish national radio, "The French speaker noted the beauty and harmony of the Ukrainian song» [19, p. 3]. With these words he mentioned the game of the Ukrainian quintet under the guidance of M. Bilyk. They collected positive feedback about their songs and ordinary Ukrainians: «My neighbors, the American, the Germans, and even the Poles talk about this performance only the best» [9, p.3], - the 
inspired listener shared the impressions after listening to the Ukrainian radio program in 1929 .

In an appeal to the society of the leadership of the Ukrainian-American Radio Organization in 1930, it was said: "A people who has hidden cultural values does not show them, then, in their or his enemy's will, appears in the eyes of others as a people without development, without culture» $[17, \mathrm{p} .3]$. Ukrainians always had something to tell the world about, than to amaze and inspire, but often such messages were the subject of manipulation. I. Bukata, the head of the authority above the radio organization, admitted that «since the invention and distribution of radio, that the best propaganda test is radio" [17, p. 3]. At the same time, M. Komichak, who in 1950-2014. was the author and presenter of the "Ukrainian radio program" on the radio "WPIT" in Pittsburgh (USA) singled out three directions (front) of the liberation movement of Ukrainians: "the front of arms resistance, the front of diplomatic work and the front of propaganda» $[16, \mathrm{p} .3]$.

Conclusions and perspectives. Ukrainian radio in the world actively worked and established the feasiblibility of countering the hostile information attacks, which today we call the manifestations of a hybrid war. Ukrainian language and music on the radio waves of the twentieth century were powerful components to counteract these threats, and also contributed to the formation and popularization of national culture at the international level. Thanks to these efforts, the heart of the preservation and development of the living Ukrainian language in the last century became the foreign radio space frequented by the world community of Ukrainians.

Gratitude. The author expresses the deep gratitude to the translator Alexandra Zerniak, for the opportunity to present an article in English to the honorable scientific community.

1. A. H. (1929), «Ukrainian song on the radio», Ukrainian weekly «Svoboda», no 204, p. 3.

2. "Presentations about Eastern Galicia in Lithuanian radio», (1928), Ukrainian weekly «Svoboda», no 102, p. 1.

3. «From Bolshevik-Ukrainian propaganda», (1944), Ukrainian weekly «Svoboda», no 252, p. 4.

4. «From Ukrainian life in America», (1935), Ukrainian weekly «Svoboda», no 18, p. 3.

5. Rizun, V., Hoian, O., (2011), «History of Ukrainian TV: first broadcast: materials of sciences. colloquium, 17 november. 2010», Kyiv National Taras Shevchenko University, Kyiv, 123 p.

6. Karavanskyi, S. (2000), «Searching for the Ukrainian word (Sections from the upcoming book)», Almanac of the Ukrainian National Association for the year 2000, p. 177-186.

7. K-lia, Z. (1928), «M. Mentsinskyi at the Stockholm radio», Ukrainian weekly «Svoboda», no 117, p. 1 .

8. Amateur Radio (1928), "Again, Ukrainian music appears as Russian», Ukrainian weekly «Svoboda», no 162 , p. 3.

9. M.B. (1929), «Quiet workers», Ukrainian weekly «Svoboda», no 209, p. 3.

10. Marusevych, S. (1944), "Young people and Ukrainian music», Almanac of the Ukrainian National Association for the year 1944, p. 197-201.

11. "Our song is in a foreign country», (1925), Ukrainian weekly "Svoboda», no 94, p. 2.

12. «New Ukrainian singer», (1926), Ukrainian weekly «Svoboda», no 58, p. 1.

13. Savytskyi, R. (2000), «In the orbit of world music (composer legacy of the XXI century)», Almanac of the Ukrainian National Association for the year 2000, p. 125-133.

14. Savytskyi, R. (2002), "Music as a Representative of the People (To the 50th Anniversary of the Ukrainian Musical Institute of America)», Almanac of the Ukrainian National Association for the year 2002, p. 169-174.

15. Svitozir (1929), «Ukrainian hour on the radio», Ukrainian weekly «Svoboda», no 48, p. 3.

16. Stakhura, R. (1952), «Viche in favor of the UCCA», Ukrainian weekly «Svoboda», no 312, p. 3.

17. «In the case of the Ukrainian clock on the radio» (1930), Ukrainian weekly «Svoboda», no 90, p. 3.

18. «Ukrainian Radio Concert in Germany» (1924), Ukrainian weekly «Svoboda», no 252, p. 1.

19. «Ukrainian songs in the Spanish Radio» (1952), Ukrainian weekly «Svoboda», no 142, p. 3.

20. «Ukrainian radio broadcasts in Brazil» (1951), Ukrainian weekly «Svoboda», no 160, p. 3. 
21. «Ukrainians are singing at the Radio concert» (1922), Ukrainian weekly «Svoboda», no 239 , p. 3.

22. F.S. (1984), «Kergonkton», Ukrainian weekly «Svoboda», no 27, p. 4.

1. А. Г. Українська пісня а радіо / А. Г. // Український тижневик «Свобода». -1929 . - № 204. - C. 3.

2. Виклади про Східню Галичину в литовському радіо // Український тижневик «Свобода». - 1928. - №102. - С. 1.

3. 3 большевищько-української пропаганди // Український тижневик «Свобода». - 1944. №252. - C. 4.

4. 3 українського життя в Америці // Український тижневик «Свобода». - 1935. - №183. - C. 3 .

5. Iсторія українського телебачення: перший ефір : матеріали наук. колоквіуму, 17 листоп. 2010 р., Київ / ред.: В. Різун; упоряд.: В. Гоян; Київ нац. ун-т ім. Т. Шевченка, Ін-т журналістики, Телерадіоклуб. - К. : Вид-во Європ. ун-ту, 2011. - 123 с.

6. Караванський C. Пошук українського слова (Розділи з майбутньої книжки) / С. Караванський // Альманах Українського народного Союзу. - 2000. - С. 177-186.

7. $K$-ля 3. $M$. Менцінський у стокгольмському радіо / З. К-ля // Український тижневик «Свобода». - 1928. - № 117. - С. 1.

8. Любитель Радіо. Знов українська музика фігурує як російська / Любитель Радіо // Український тижневик «Свобода». -1928. - № 162. - С. 3.

9. М. Б. Тихі робітники / М. Б. // Український тижневик «Свобода». - 1929. - № 209. - С. 3.

10. Марусевич C. Молодь і українська музика / С. Марусевич // Альманах Українського народного Союзу. - 1944. - С. 197-201.

11. Наша пісня на чужині // Український тижневик «Свобода». - 1925. - № 94. - С. 2.

12. Новий український співак // Український тижневик «Свобода». - 1926. - № 58. - С. 1.

13. Савицький P. В орбіті світової музики (композиторська спадщина га грані XXI віку) / Р. Савицький // Альманах Українського народного Союзу. - 2000. - С. 125-133.

14. Савицький Р. Музика як представник народу (До 50-річчя Українського музичного інституту Америки) / Р. Савицький // Альманах Українського народного Союзу. - 2002. C. $169-174$.

15. Світозір. Українська година на радіо / Світозір. // Український тижневик «Свобода». - 1929. - № 48. - С. 3.

16. Стахура Р. Віче на користь УККА / Р. Стахура // Український тижневик «Свобода» . - 1952. - № 312. - С. 3 .

17. У справі української години на радіо // Український тижневик «Свобода». - 1930. № 90. - C. 3 .

18. Український радіоконцерт в Німеччині // Український тижневик «Свобода». - 1924. - № 252. - C. 1 .

19. Українські пісні в Еспанському радіо // Український тижневик «Свобода». - 1952. - № 142. - С. 3.

20. Українські радіопередачі в Бразилії // Український тижневик «Свобода». - 1951. № 160 . - C. 3 .

21. Украӥнці співають на Радіо-концерті // Український тижневик «Свобода». - 1922. № 239 . - C. 3 .

22. Ф. С. Кергонкстон / Ф. С. // Український тижневик «Свобода». - 1984. - № 27. - С. 4.

УДК $316.77: 070: 654.195: 314.743$

\section{ПРОМОВЛЕНЕ ТА ПРОСПІВАНЕ НА РАДІО УКРАЇНСЬКЕ СЛОВО НА ВАРТІ ЗБЕРЕЖЕННЯ НАЦІОНАЛЬНОГО КУЛЬТУРНОГО КОДУ В ЕМІГРАЦІЇ}

\section{Гиріна Тетяна, канд. наук із соц. комунік., доц., докторант,}

Інститут журналістики КНУ імені Тараса Шевченка, вул. Мельникова, 36/1, м. Київ, 04119, Україна, e-mail: hirinatetyana@gmail.com

ORCID - https://orcid.org/0000-0003-1587-8767

Вступ. В українській науковій думці досі комплексно не осмислено надбання та досвід зарубіжних українців зі створення національного патріотичного радіопродукту в умовах зовнішніх викликів та об’єктивних внутрішніх проблем, які стояли перед громадою. 
Актуальність. Історичний контекст цього питання в аспекті використання української мови як маркера національної ідентичності та патріотизму розглянемо у цій статті.

Мета роботи - дослідити роль та описати цінність рідної мови у радіопрограмах продукованих українцями в різних країнах як потужного інтеграційного чинника глобальної української громади у XX ст.

Методологія. Виконання поставлених автором завдань стало можливим завдяки використанню комплексу теоретичних та теоретико-емпіричних методів дослідження: аналізу, джерелознавчого пошуку, індукції, історіографічного методу, методу моніторингу періодичних видань, синтезу та систематизації даних.

Результати. Моніторинг пресових органів української діаспори в США, Канаді та Нiмеччині охопив понад 14500 чисел видань у 1922-2017 pp,, що у підсумку дозволило документально підтвердити наявність українськомовних радіоініціатив в радіопросторі 32 країн світу: Австралія, Австрія, Аргентина, Бельгія, Бразилія, Ватикан, Великобританія, Венесуела, Голландія, Іспанія, Італія, Казахстан, Канада, Китай, Литва, Мальта, Німеччина, Нова Зеландія, Парагвай, Польща, Португалія, Румунія, Сербія, Сінгапур, Словаччина, США, Туніс, Угорщина, Уругвай, Чехія, Чилі та Швеція. Встановлено, що у різні роки українські години звучали в радіоефірі 141 міста на всіх континентах. Ширша географія програм простежувалася в місцях оформлення активних осередків українства, утім навіть за мінімальних можливостей намагалися ініціювати якщо не постійну, то принаймні святкову, неперіодичну музичну програму чи Службу Божу, як це було у Тунісі в $1949 \mathrm{p}$.

Висновки. У XX ст. українське радіо у світі активно налагоджувало посильну роботу з протидії ворожим інформаційним атакам. Українська мова та музика в радіоефірі були потужними складовими протидії цим загрозам, а також сприяли формуванню та популяризації національної культури на міжнародному рівні. Центром зі збереження та розвитку живої української мови став зарубіжний радіопростір акумульований світовим співтовариством українців.

Ключові слова: світове медіасередовище, світове співтовариство украӥнців, українська пісня, українськомовне радіо.

Стаття надійшла до редакції 22.06.2018 